<症例報告 $>$

高分化型肝細胞癌か肝細胞腺腫か鑑別が問題になった 巨大結節状肝腫瘍の 1 例

$\begin{array}{llllll}\text { 小暮 } & \text { 公孝 } & \text { 石崎 } & \text { 政利 } & \text { 加藤 } & \text { 良二 } \\ \text { 根本 } & \text { 雅明 } & \text { 小川 } & \text { 晃男 } & \text { 塚田 } & \text { 勝彦 } \\ \text { 服部 } & \text { 徳昭 } & \text { 長町 } & \text { 幸雄* } & \text { 笹本 } & \text { 潔** }\end{array}$

要 旨：38藏男性の肝左葉に原発した巨大結節状肝腫場を切除したが, 腫場は大小の血管に富 む厚い、被膜に包をれ，腫場細胞は比較的形の整った正常肝細胞に類似した索状構造を呈し類洞 により隔てられていた。 また，核の大小不同，变形は軽微で有系分裂像は見い出しえなかった。 非腫瘍部は全くの正常肝であった。

血管造影では腫瘍を囲んだ 2 本の太い $\mathrm{S}_{2}, \mathrm{~S}_{3}$ の血管から内部に向って栄盖枝が分枝していた が, 血管の断裂, 閉塞, 不整像は認められなかった. CT では正常肝よりややlow density を呈 したが，腫煌内に出血巣を思わせる low density area が散在性に認められた。

$18 \times 19 \times 6 \mathrm{~cm}, 1500 \mathrm{~g}$ の腫境切除後, 4 年 6 力月再発の徵候は全く認められていない.

本例は組織学的には高分化型肝細胞癌との鑑別は難しいものの, 画像診断上, 臨床経過上の 特徵を加味して肝細胞腺腫と診断した。

類似する17例の本邦報告例る併せ検討した。

索引用語：巨大結節状肝細胞癌 高分化型肝細胞癌 肝細胞腺腫

\section{I. 緒 言}

肝細胞腺㾖は極めて稀な疾患1て病理形熊学的にも 高分化型腺癌との鑑別は容易でなく, 画像診断, 臨床 経過の检討も加光て総合的に診断されなけれい゙ならな いとされている2゙.

著者等は 4 年 6 力月前に 38 葴男性の肝左葉に原発し た巨大結節状肝腫瘍を切除したが，組織学的には高分 化型肝細胞癌との鑑別は難しいながらも, 病理形態学

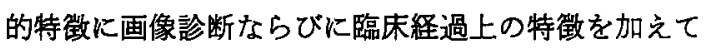
検討した結果, 肝細胞腺盾と詥断した 1 例を経験した ので報告する。

本症例は骨船に達する巨大結節状の肝腫場で太い血

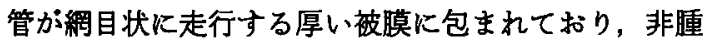
㻛部は全くの正常肝で肝機能も正常値を示し AFP, HBs-Ag, HBs-Abはいずれも陰性であった。本症例の 上らに背景が正常肝で被膜に包をれた巨大結節状を呈 し, しかも AFP の産生が認められず HBs-Ag, HBs-

\footnotetext{
*群馬大学第 1 外科

** 済生会前橋病院外科
} 〈受付日61年 8 月 6 日 $>$
Ab 䧔性とい5肝腫瘍は従来, “巨大肝細胞癌3””, “巨 大腫瘤形成肝細胞癌4)”，“巨大高分化型肝細胞癌5)”之 して報告されているが, 稀に“肝細胞腺腫の”の診断がな されて報告されている，いずれも巨大結節状を呈しそ の臨床経過もいわゆる "slow growing hepatoma ${ }^{3,5}$ " の範鲭に入り極めて良好である。

著者等は自験例に類似した, 背景が正常肝でAFP, HBs-Ag，HBs-Abがいずれむ陰性という性格を有す。 る巨大肝腫場の本邦報告例を文献上17例集約7 10) した ので自験例と関連させ若干の文献的考察を加えて報告 する.

\section{II. 症例}

患者：38歳，男性.

主訴：右上腹部痛, 腹部膨満感。

既往歴：数年前より胃炎といわれる。

家族歴：特記すべきことなし．

現病歴：1982年11月中旬, 右上腹部痛が出現したた め某医を受診したところ胆亳炎の診断を受けたが，右 上腹部痛が持続したにもかかわらず放置していた。 11 月下旬, 右上腹部痛之腹部膨満感が増強したため外来 


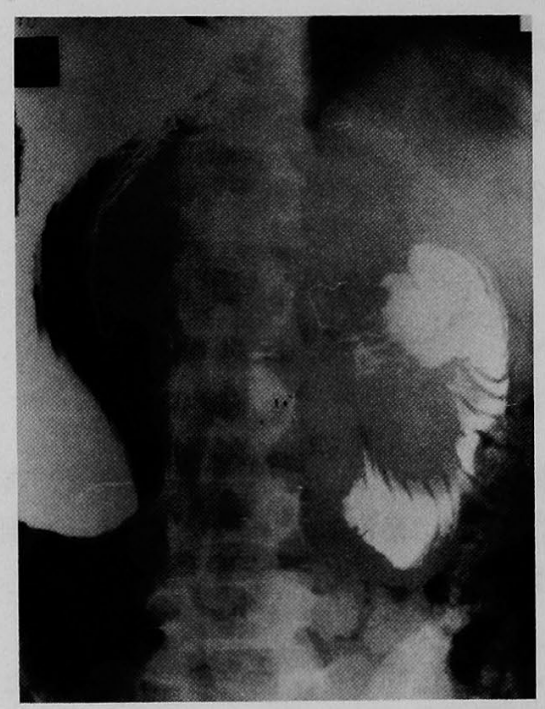

Fig. 1 The upper gastrointestinal roentgenographic series revealed partial displacement of the stomach by an external mass. (prostrate position).

を受診し触診で上腹部に腫瘤を触知したため精査目的 で入院となった.

入院時所見：体重 $49 \mathrm{~kg}$, 血圧 $130 / 60 \mathrm{mmHg}$, 脈拍 $98 /$ 分，眼瞼結膜に軽度費血を認めるが，眼球の黄染は認 めない，胸部異常なし，腹部は全般に膨満し脆下部に 到る辺縁鈍で強性軟の呼吸性移動を有する腫瘤を触知 するが圧痛は認めない，また，腹水，腹壁の静脈怒張， 脾腫大，下肢の浮腫は認めない。

検查所見：血色素 $9.5 \mathrm{~g} / \mathrm{d} l$, 赤血球 $381 \times 10^{4}$, 白血球 9.900 ，へマトクリット $33.4 \%$ ，血小板 629,000 , 血浆 蛋白 $6.8 \mathrm{~g} / \mathrm{d} l$, 総ビリルビン $0.7 \mathrm{mg} / \mathrm{d} l, \mathrm{GOT} 19 \mathrm{KU}$, GPT 23KU, LDH 343WU, AL-P 4.6, TTT 1.0, ZTT 4.6, CRP 2+, BUN $31.4 \mathrm{mg} / \mathrm{d} l$, HBs-Ag (-), HBs$\mathrm{Ab}(-)$, AFP $(-)$, CEA $(-)$, PT114\%, APTT $50.1 \mathrm{sec}$ と軽度費血と血小板増加，ならびに軽度尿素 窒素の増加が認められたが，肝機能，血液凝固系は全 く正常であった。

入院時画像診断所見：胃透視所見 (Fig. 1)：腹臥位 で胃体上部から十二指腸球部にかけて腫瘍による半球 形の王排像が認められる。特に幽門部は圧排伸展され 細長くなっているが通過障害は認められない。

血管造影所見 (Fig. 2)：右肝動脈は上腸間膜動脈か ら分枝しているため Fig. 2 の腹腔動脈造影では描出 されていない，腹腔動脈からは太く増大した左肝動脈
28巻 4 号（1987）

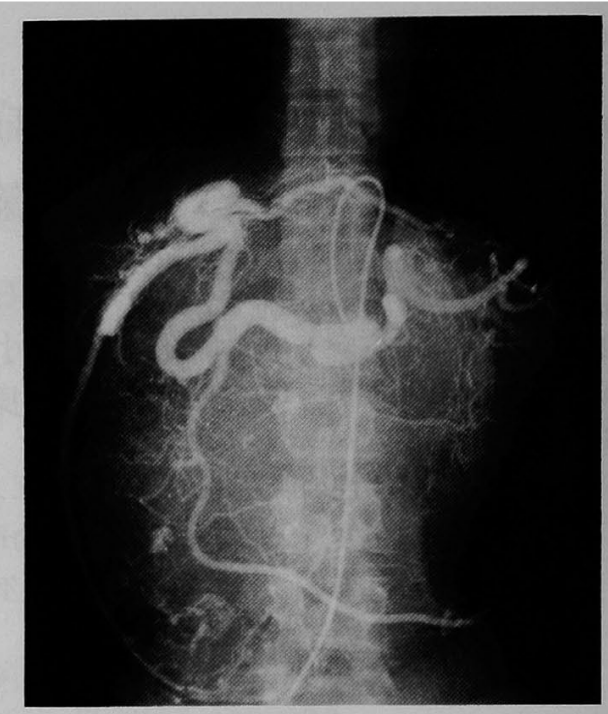

Fig. 2 Hepatic arteriogram demonstrates the large, well-circumscribed mass which ocupies most of the abdominal cavity. Vascular supply originates the two branches of left lateral hepatic artery which surround the tumor from the upper and lower sides.

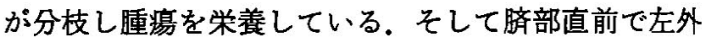
側区域上行枝を分枝し盿部で左外側区域下行枝を分枝 しているが増大した両血管は球状の腫瘍の表面を取り かこむように走行し，周辺より目湯内部に向って多数 の細い栄養血管を分枝している.両血管には壁の不整, 断裂，屈曲は認められなかった，左内側区域枝はわず かに認められるが腫煬を栄養してはいなかった。 上記 から本腫煬は巨大結節状を呈するにるかかわらず左外 側区域枝のみで栄養される左外側区域原発の肝腫場で 血管造影の所見からは良性の肝腫湯と考えられた。

CT 所見 (Fig. 3)：腫場部は表面平滑で非腫湯部よ り軽度低濃度影を示し，また造影剂の enhancement でも非腫場部に比し軽度低濃度影を示した，更に腫㻛 内には出血巣を思わせる不整形の中等度低濃度領域を 散在性に認めた。

超音波所見 (Fig. 4)：図は術中超音波像である．左 肝静脈と中肝静脈が腫場内側で分枝しその左方に腫掦 への複数の栄養血管が横断像で描出されている。畽場 は全般に hypoechoic に描出され，腫場下では音響増 強効果が認められた。

術前経過，血管造影の際，MMC 10mg を動注した が，その後，蝩掦は若干の縮小をみた。手術知見(Fig. 


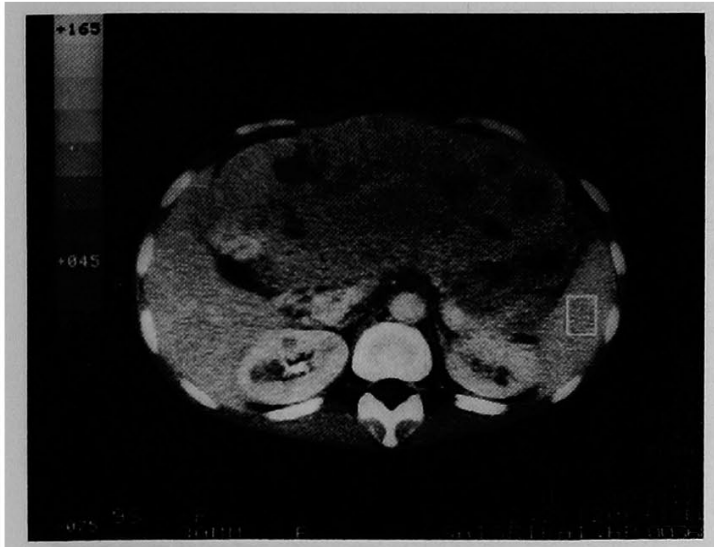

Fig. 3 Postcontrast CT scan shoes well-defined $18 \times 19 \mathrm{~cm}$ mass occupying left lobe of liver. A low density area represents hemorrhage or necrosis within the lesion.

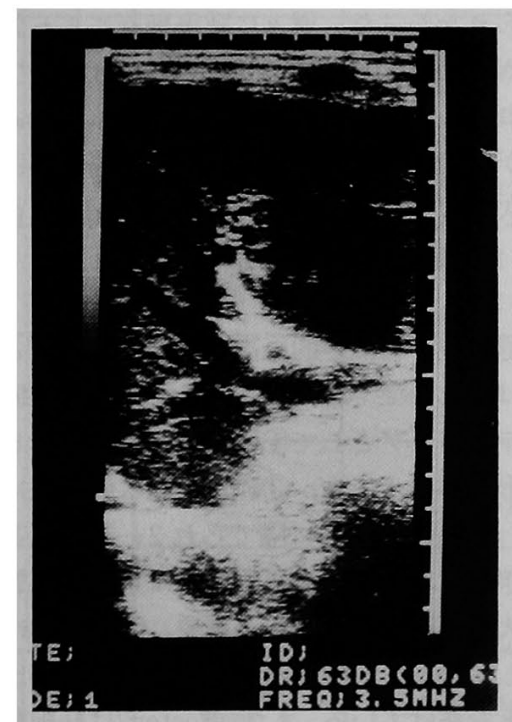

Fig. 4 Ultrasonography revealed a large mass in the left lobe and especially enlarged left and middle hepatic veins whose multiple branches drained the tumor.

5A・B）正中切開に更に右肋弓下切開を加え開腹した。 腹水は認められず非腫瘍部は正常肝で腫湯は鎌状靯帯 の左側にあり左外側区域全体を占め臍下部に到る巨大 結節状を呈乙厚い被膜に被われ，その被膜内には錯綜 する大小の血管の拍動が透見された，また，畽煬自体 は大変柔かく血液に富むため弾力性があり外見上なら びに触診上では充実性腫薂とは考党られなかった。 肝門部で左肝動脈，左門脈本幹を結禁切断したのち

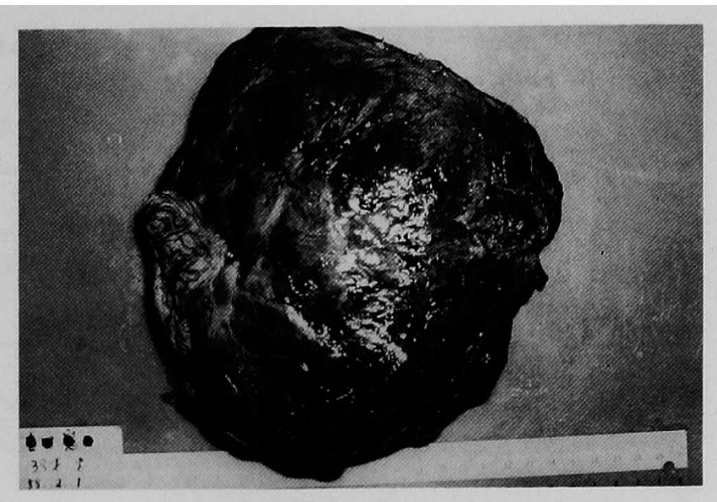

(A)

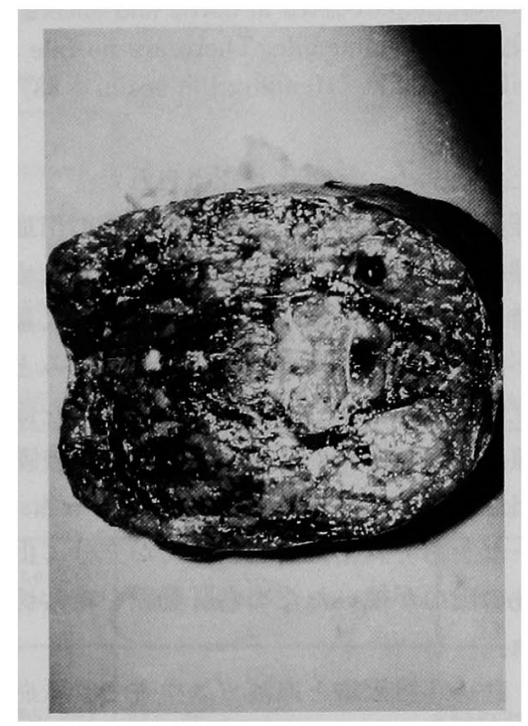

(B)

Fig. 5 Gross appearance of lesion. The tumor, which was surrounded by a fibrous capsule, had a soft consistency, weighed $1,500 \mathrm{~g}$ and measured $18 \times 19 \times 16 \mathrm{~cm}$. Its surface was irregulary lobulated.

A : Operative specimen of the tumor.

$B$ : Section of the tumor.

被膜に沿って豏状靯帯の左側で腫場の切除をすすめ た，畽瘍と非尰晹部の間には太い栄盖血管ならびに肝 静脈枝が交通しており切離の際大量の出血をみたが断 端の刺絡繾合により止血しえた。しかし，この止血操 作の際，肝右葉前下区域の被膜を損偤しそこより湮漫 性の出血が認められたためオキシセル綿をあて压迫止 血を行って閉腹した。

切除尰瘍重量は1500g，大きさは $18 \times 19 \times 6 \mathrm{~cm} て ゙$ あったが切除前の重瘍の大きさよりも内部の血液が失 


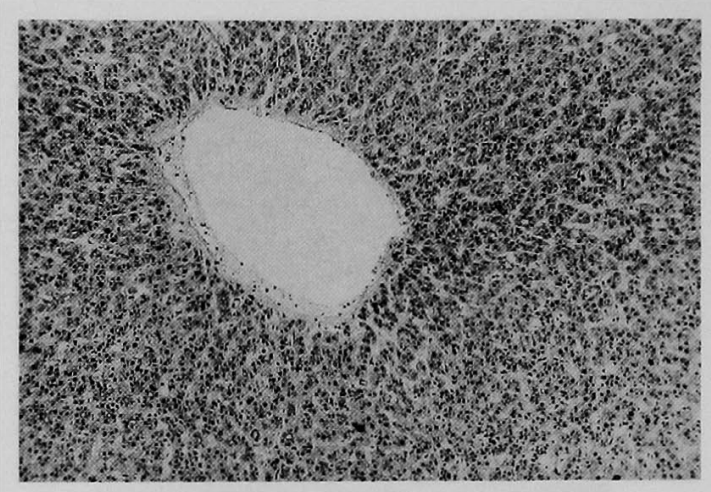

Fig. 6 Microscopic findings. The tumor consists of mature hepatocytes in cords and sheets, with rarely intracellular bile. There are no bile ducts or biliary triads. (Hematoxilin-eosin, $\times 88$ )

なわれたため縮小，軽量化が認められた。

術後経過，術後ドレーンからの持続性の出血が続き 血圧も翌朝午前11時には104/70に下降したため翌日の 午後 8 時から再開腹を行った. 腹空内には大量の血液 凝血塊が認められ肝右葉の被膜下に血腫がみとめられ 被膜は全体に放満腫大していた。この血腫を除去する と出血源は初回手術時の肝右葉前下区域の被膜損傷部 からの出血であったのでこれにオキシセル綿，オキシ セルガーゼをあて刺絡止血を行ったが充分に止血しえ す唡漫性の出血が続いたため右肝動脈を結愁切断し止 血しえた。

術後, 軽い呼吸困難と血液ガス検查で動脈血酸素分 王が50台に低下し軽いARDS 状態に陷ったが，吸入， IPPB 等の lung physiotherapyを行った結果, 術後 1 週間を過ぎたころからは血液ガスも正常值に近つき術 後 2 カ月で軽快退院した。

組織所見 (Fig. 6,7)：腫煬は厚い線維性被膜に包ま れ，その被膜内には多数の太い血管が走行しているが 腫場細胞の浸潤は全く認められなかった。また，腫瘍 内には肝静脈に類似した血管が散在性に認められその 周囲には索状構造を呈する畽瘍細胞が充実性に配列し ていたが，その腫場細胞は正常肝細胞に類似し比較的 形が整い類洞により隔てられある部分では一層の索 状構造を呈し，また他の部分では $2 \sim 3$ 層の厚さを もった索状構造を呈しているが，稀に細胞密度の高い 部分が focal に認められた，核は比較的大きく明瞭で 核膜はやや厚く中にはっきりとした核仁を有するが核 の大小不同，変形は殆ど認められなかった。 また， 2 核を有する細胞がところどころに散見され盛んな増殖

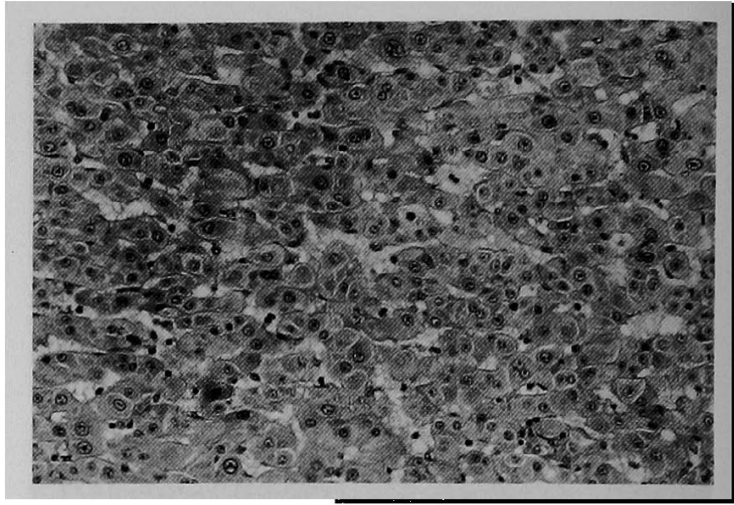

Fig. 7 Microscopic findings showed the uniform pattern of liver cell cords, in which significant nuclear atypia or mitoses could not be seen ( $X$ 560 ).

活動を呈していたことが予想されたが有糸分裂像は全 く認められなかった，所々に董瘍細胞による偽腺管形 成部分が認められ一部に bile pigmentを含むものも 認められたまた，腫場細胞内にも bile pigment を含 むものが少数ながら認められたが，腫場内には胆管系 は全く欠如していた。 また, mallory body き globular body も全く認められなかった.

\section{III. 考 察}

肝細胞腺腫を組織学的に高分化型肝細胞癌と区別す ることは難しいとされる。太田6)は肝細胞腺腫の診断 上のクライテリフとして(1)背景は正常肝であること, (2)被膜形成があること, (3)腫瘍細胞は肝細胞に類似し 同大で，㹟い sinusoidに隔てられ 2，3列に並んだ細 胞柱がぎっしりつまっている. 核は正常肝細胞と同大 か小，大小不同が無いことが重要，(4)腫瘍内に胆管系 を欠如している，(5)腫煌内部に凝固壊死部や出血巣を 含むことを挙げている．また, Foster ${ }^{2}$ は肝細胞腺腫は 大きな柔かい尰埸で, 表面は平滑で中心陣凹が無く， 割面では壊死部や出血部がみられ，中心部に scar が時 にみとめられること，また，組織学的には単一の細胞 構造を示すが小葉構造はつくらず, 門脈, 中心静脈を 欠如すること，そして多くは明るい細胞質を有し，核 の多形性はFNH上りむ強いむのの有系分裂像は認め られないこと, 非腫湯部とは線維性の被膜で境界され 出血巣を有すること, 胆管系は欠如するが時に胆汁の らっ滞を示すこともあること，を診断上の特徵として あげている．しかし，境界領域にある高分化型肝細胞 癌との鑑別は難しく多数の切片に基つく検索が必要で あるとしている。 
Table 117 cases of the encapsulated liver tumors belonging to the same category of our case (HBs-Ag $(-)$, HBs-Ab $(-)$, AFP $(-)$, a normal liver in non-tumor part and a good survival) were collected in Japanese literature.

\begin{tabular}{|c|c|c|c|c|c|c|c|c|}
\hline Case & Age & $\operatorname{sex}$ & $\begin{array}{l}\text { Location } 8 \\
\text { Tumor size }\end{array}$ & Capsule & $\begin{array}{l}\text { Hictolog } 1 \mathrm{cal} \\
\text { f1ndings. }\end{array}$ & Treatment & $\begin{array}{l}\text { Survival time(") } \\
\text { Additional findings }\end{array}$ & Reporter \\
\hline 1 & 18 & $\mathbf{F}$ & $10 \mathrm{~s}$ & + & $\begin{array}{l}\text { Trabecular type } \\
\text { Liver cell } \\
\text { adenoma }\end{array}$ & Tumor excision & $4 y x *$ & Takeuch1 ${ }^{6}$ ) \\
\hline 2 & 45 & $\boldsymbol{F}$ & & + & $\begin{array}{l}\text { Liver cell } \\
\text { adenoma }\end{array}$ & $\begin{array}{l}\text { S6-Subsegment- } \\
\text { ectomy }\end{array}$ & lyr" & Nakamura $a^{6}$ ) \\
\hline 3 & 42 & & & + & No atypia & $\begin{array}{c}\text { L.L. lobectomy } \\
\text { r-Local excision }\end{array}$ & $\begin{array}{l}\text { 5yr 9m* } \\
\text { Abdominal tumor was } \\
\text { Indicated since } 10 \text { yro } \\
\text { ago. }\end{array}$ & $I\left(0^{6)}\right.$ \\
\hline 4 & 36 & $\mathbf{F}$ & & + & $\begin{array}{l}\text { Trabecular type } \\
\text { Infiltration to } \\
\text { Capsule }\end{array}$ & R1ght lobectomy & $\begin{array}{l}\text { lyr } 1 \mathrm{~m} * \\
7 y r 5 m \text { ago pt was diag- } \\
\text { nosed as HCC and was } \\
\text { delivered of 2nd infan }\end{array}$ & Wakasa $\left.{ }^{6}\right)$ \\
\hline 5 & 71 & $M$ & & + & $\begin{array}{l}\text { Trabecular type } \\
\text { Ed II-III }\end{array}$ & L.L. lobectomy & $8 \mathrm{yr} 4 \mathrm{~m} *$ & Koj1ma ${ }^{7)}$ \\
\hline 6 & 39 & $F$ & & + & Ed I-II & $\begin{array}{l}\text { Right Inferior } \\
\text { Begmentectomy }\end{array}$ & $\begin{array}{l}4 y r 4 \mathrm{~m}^{*} \text {. } \\
4 \mathrm{yr} 5 \mathrm{~m} \text { ago pt was d1ag- } \\
\text { nosed as HCC. }\end{array}$ & Kubo ${ }^{7)}$ \\
\hline 7 & 32 & $\mathbf{F}$ & & + & Ed I I & Right lobectomy & $17 y x 2 \mathrm{~m}$. & Nakan1sh1 ${ }^{7}$ \\
\hline 8 & 17 & $\mathbf{p}$ & & + & Ed I-II & Left lobectomy & $8 y x^{*}$ & Tanno 7$)$ \\
\hline 9 & 39 & M & & $\begin{array}{l}\text { not } \\
\text { stated }\end{array}$ & not stated & $\begin{array}{l}\text { Right posterior } \\
\text { local excision }\end{array}$ & $12 \mathrm{yr} 2 \mathrm{~m}$ & K1mura ${ }^{7)}$ \\
\hline 10 & 68 & $M$ & & $\begin{array}{l}\text { not } \\
\text { stated }\end{array}$ & 2d II-III & Right lobectomy & $3 \mathrm{yr} 8 \mathrm{~m}$, & K1mura ${ }^{7)}$ \\
\hline 11 & 62 & $\mathbf{M}$ & & + & not stated & Left lobectomy & $\begin{array}{l}\text { 8yr } 8 \mathrm{~m} \text {. } \\
\text { died of myocardial } \\
\text { Infarct }\end{array}$ & Nagao ${ }^{7}$ \\
\hline 12 & 34 & $\mathbf{F}$ & & + & $\begin{array}{l}\text { Trabecular type } \\
\text { Ed II-III }\end{array}$ & $\begin{array}{l}\text { Radiation } \\
2200 \text { rad }\end{array}$ & $\begin{array}{l}\text { Abdominal tumor was } \\
\text { lndicated since } 4 \mathrm{yr} 5 \mathrm{~m} \\
\text { died of HCC. }\end{array}$ & $\operatorname{kat0^{7)}}$ \\
\hline 13 & 33 & $\mathbf{F}$ & & + & Trabecular type & $\begin{array}{l}\text { Local excision } \\
\text { of right lobe }\end{array}$ & $\begin{array}{l}7 y y^{*} \\
2 y r \text { \&yr after ope } \\
\text { the pt was delivered } \\
\text { of } 1 \text { nfants. }\end{array}$ & $\operatorname{Th}^{8}{ }^{8)}$ \\
\hline 14 & 71 & $\mathbf{M}$ & & + & Trabecular type & Autopsy & $\begin{array}{l}\text { Liver tumor was } \\
\text { lndicated since } 5 y r \\
\text { ago. Died of senility. }\end{array}$ & Suzuk1 ${ }^{9)}$ \\
\hline 15 & 39 & $\mathbf{F}$ & & $\begin{array}{l}\text { not } \\
\text { Btated }\end{array}$ & $\mid \begin{array}{l}\text { Ed I } \\
\text { Resemble to LCA }\end{array}$ & Local excision & good survival & Arakawa ${ }^{4)}$ \\
\hline 16 & 68 & M & & + & $\begin{array}{l}\text { Trabecular type } \\
\text { Bd II-III }\end{array}$ & $\begin{array}{l}\text { Extended r1ght } \\
\text { lobectomy }\end{array}$ & $\begin{array}{l}\text { Iyr", } \\
\text { Liver tumor was } \\
\text { lndicated since 3yr } 11 \mathrm{~m} \\
\text { ago. }\end{array}$ & Yasunar $1^{3}$ \\
\hline 17 & 63 & $\mathbf{M}$ & & + & Ed III & L. L. lobectomy & $\begin{array}{l}\text { Right hypochondral } \\
\text { swelling was indicated } \\
\text { since } 2 \text { yr ago. } \\
\text { good survival }\end{array}$ & Taketani 10$)$ \\
\hline
\end{tabular}


自験例は竹内6)の報告している肝細胞腺腫の手術時 の所見と全く類似し，厚い被膜に被われ多数の太い血 管が腫瘤をとりかこむよらに走行し大きな拍動が認め られ，また割面でも散在する出血巣とそれが線維化し たと考兄れる線維性の結合織の走行が認められる.

また，自験(例は竹内 ${ }^{6)}$ ，若林 ${ }^{6}$ の報告している肝細胞 腺腫の組織像上り若干分裂增殖の勢いが強く，細胞が 偽腺管状に配列し bile pigment す稀に認められる所 見も存在することから一方では高分化型肝細胞癌への 移行を示しているとも考えられた。 しかし，多数切片 の検索から太田のの示したクライテリアをほぼ満足し ているものと考光肝細胞腺腫と診断した。

肝細胞腺腫の血管造影上の特徽は被膜を走る太い栄 盖血管が伸展圧排され腫場をとりかこみながら内部に 向って栄着枝を分枝し，毛細血管レベルでは非浸潤性 であり A-P shuntを認めないとされている11,12)，CT 上の特徵としては low density lesionとして示され， 造影剤による増強効果も非腫場部よりも小さく，散在 性に出血巣を認めるとされる ${ }^{12)}$.また, 超音波像では特 有の所見を呈しないとされる ${ }^{12)}$ ．前述したように自験 例では上記の肝細胞腺腫の画像診断上の基本的特徵を 全てそなえているものと考えられた。

本症例のような基本的特徵を有する肝腫瘍の臨床経 過に関して幕内 ${ }^{3)}$ ，銭谷 ${ }^{5}$ 等は相当期間静止状態にあっ た肝腫瘍がある時期から急速に増大悪性化する過程が 存在するのではないかと指摘している，著者等が集約 した本邦報告例のなかでも No. $3^{6)}$, No. $4^{6)}$, No. $6^{7}$, No. $10^{7)}$ ，No. $12^{7}$ ，No. $17^{10}$ 症例では手術までに長期 間肝腫湯が観察されており，乙かる腫湯切除後る再発 は認められず, 特にNo. $4^{6)}$, No. 1383症例では術後妊 娠し 1 児をあうけている (Table 1)。これらの各肝畽 瑒いずれにる共通する特徽として，被膜を有する結節 性の腫喈で sinusoidに隔てられた 1 ～㬝よりなる 肝細胞索が充満する索状構造を呈し，臨床経過は非常 に良好であること，が認められた。

中島 ${ }^{13)}$ 等は肝細胞癌の予後に言及する時に被包型肝 細胞癌は他の肝細胞癌に比し非常に予後が良好なこと から除外して考えるべきであると指摘しているが，本 症例ならびに表に示したような肝腫掦は他の組織型を 有する肝細胞癌や肝硬变を合併する肝細胞癌とは異 なった独立の性格を有する肝腫場として取り报らべき であると考えられた。

本症例では直接, 被膜に沿って腫湯を切除しており 完全な TW (+) であるにもかかわらず 4 年 6 カ月を
経過した現在でも再発の徵候は全く認められておら ず，手術後の良好な臨床経過からも原発巣は良性の性 格を強く保持するものと考えられた。

$$
\text { IV. 結 語 }
$$

38歳，男性の正常肝に発生した巨大結節状肝腫湯を 切除したが, 組織学的には高分化型肝細胞癌との鑑別 は難しいものの, 肉眼的, 画像診断上, 臨床経過上の 特徵を加味して検討した結果, 肝細胞腺腫と診断した。

また，本症例と同様の特徵を有する17例の本邦報告 例を集約してその基本的特徵を併せ検討した。

\section{文献}

1) Edmondson HA: Tumors of the liver and intra-hepatic bile ducts. In: Atlas of tumor pathology, Armed Forces institute of Pathology, Washington, DC, 1985, section 7 fascicle 25 , p193-206

2) Foster JH, Berman MM: The benign lesions: Adenoma and focal nodular hyperplasia. In: Solid liver tumor, W.B. Saunders Company, Philadelphia, 1977, p138-178

3）宮成茂樹，幕内雅敏，新星誠一郎，他：3 年11力月 の経過観察の後に切除し得た巨大肝細胞癌の 1 例. 一Slow growing hepatoma18例と巨大肝細胞 癌切除症例16例の検討一. 肝臓 $26: 515-523$, 1985

4）荒川正博，鹿毛政義，磯村 正，他：原発性肝癌の 病理形態学的研究一肝外に巨大な腫瘤を形成した いわゆる有茥性肝細胞癌7例の検討一, 肝䑏 23 ： $942-948,1982$

5）銭谷幹男，相沢良夫，秋庭真理子，他：2 年 6 力月 以上絓過した高分化型肝細胞癌の 1 症例一いわゆ る Slow growing hepatomaについて一. 肝哓 $19: 393-398,1982$

6）中島敏郎, 太田五六, 奥平雅彦, 荒川正博, 編 :「肝 細胞癌の類似病変」中外医学社, 東京, 1984, $\mathrm{p} 1-262$

7）亀田治男，編：「肝細胞癌一長期生存例の検討一」 中外医学社, 東京, 1983，p1-316

8）陳黄義平, 簡 錦鵬, 徐 福清, 他：原発性肝細胞 癌の 1 手術治験例。北関東医学 $10: 461-465$, 1960

9）鈴木泰彦, 宮城三津夫, 佐々木健身，他：肝シンチ により大きな欠椇を認めてから 5 年生存した Green hepatoma $の 1$ 剖検例. 肝䁍 $18: 297$, 1977

10）竹谷 弘, 東島哲也，池田義和，他：巨大な肝腯䁬 
に対する肝切除後の経験. 外科 $40: 134-138$, 1978

11) Kerlin P, Davis GL, McGill LH, et al : Hepatic adenoma and focal nodular hyperplasia : Clinical, pathologic, and radiologic features. Gastroenterology $84: 994-1002,1983$

12) Fishman EK, Farmlett E, Kadir S, et al :
Computed tomography of benign hepatic tumors. J Comput Assist Tomogr 6 : 472-481, 1982

13）下川 泰, 中島敏郎, 奥田邦雄, 他 : 原発性肝癌に 関する研究. 第 3 報. 肝細胞癌の中島, 奥田肉眼分 類とその臨床病理学的特徵. 肝葴 $16: 752-762$, 1975

\title{
A case report of a giant liver tumor for which it was difficult to distinguish between a liver cell adenoma and a liver cell carcinoma
}

\author{
Kimitaka Kogure, Masatoshi IshIZAKI, Ryoji Kato, Masaaki Nemoto, \\ Akio OGaWA, Katsuhiko TsUKaDA, Noriaki HatToRI, \\ Yukio NaGAMACHI* and Kiyoshi SaSAMOTo**
}

A 38 years-old man with a giant liver cell adenoma extending to the pelvis was treated by left lateral lobectomy. The tumor which was encapusulated by the fibrous membrane was $18 \times 19 \times 6 \mathrm{~cm}$ in size and weighed $1,500 \mathrm{~g}$. Histologically this tumor was composed of well-differenciated liver cell trabeculae and a small number of pseud-biliary ducts, but no Glisson's sheaths.

It is difficult to distinguish liver cell adenoma from well-differenciated liver cell carcinoma histologically. Also in our case it was difficult to diagnose it as liver cell adenoma histopathologically, however from the good survival, and the hematological and radiographical examinations its tumor was diagnosed as a liver cell adenoma.

17 similar liver tumors (normal liver, $\mathrm{HBS}-\mathrm{Ag}(-), \mathrm{HBS}-\mathrm{Ab}(-), \mathrm{AFP}(-)$ and good survival) were collected in Japanese literatures.

\footnotetext{
* Department of Surgery, Gunma University, School of Medicine (Gunma)

** Maebashi Saiseikai Hospital (Gunma)
} 